\title{
DEVELOPING THE VOLUNTARY TAXPAYER COMPLIANCE: THE SCALE OF THE TAX AUTHORITY'S POWER, TRUST AND THE FAIRNESS OF THE TAX SYSTEM
}

\author{
Atik Djajanti ${ }^{* 1}$ \\ *) Faculty of Economics and Business, Perbanas Institut Jakarta \\ Jl. Perbanas, Karet Kuningan, Setiabudi, Jakarta, 12940
}

\begin{abstract}
This study aims to analyze the scale of the power of the tax authority, trust and the fairness of the tax system for the voluntary compliance of the individual taxpayers who have businesses. The study was conducted in Jakarta and its surroundings, considering tax revenue in this region is the best compared to revenue in other regions in Indonesia. This research was a survey research. Convenience sampling method is used due to limitations in accessing individual taxpayer data. Personal data information in the tax authority was confidential. Using Partial Least Squares Structural Equation Modeling (PLS-SEM), the results of the study showed that the scale of the power of the tax authority and the trust proved to have a positive effect on the voluntary tax compliance while the fairness of the tax system had a negative effect. The results of this study support the development of the slippery slope theory which was the novelty of this study. The scale of the power of the tax authority, which is a part of the tax authority, is generally a determinant of the enforced tax compliance. But this study proves that it is also needed to the voluntary tax compliance.
\end{abstract}

Keywords: slippery slope theory, individual taxpayer, voluntary tax compliance, enforced tax compliance, PLS-SEM

Abstrak: Penelitian ini bertujuan untuk menganalisis skala kekuatan otoritas pajak, kepercayaan dan keadilan sistem pajak terhadap kepatuhan sukarela WP-OP non karyawan atau WP-OP yang mempunyai usaha. Penelitian dilakukan di Jakarta dan sekitarnya mengingat penerimaan pajak di wilayah ini merupakan yang terbaik dibandingkan dengan penerimaan di wilayah lainnya di Indonesia. Penelitian ini merupakan penelitian survey. Pengumpulan data menggunakan metode convenience sampling karena adanya keterbatasan dalam mengakses data individu WP-OP. Informasi data pribadi bersifat rahasia. Analisis data menggunakan program Partial Least Squares Structural Equation Modeling (PLSSEM). Hasil penelitian menyimpulkan bahwa skala kekuatan otoritas pajak dan kepercayaan terbukti berpengaruh positif terhadap kepatuhan sukarela sedangkan keadilan sistem pajak berpengaruh negatif. Hasil penelitian ini mendukung pengembangan teori slippery slope yang merupakan kebaharuan dari penelitian ini. Skala kekuatan otoritas pajak, yang merupakan bagian dari kekuatan otoritas pajak, umumnya merupakan determinan dari kepatuhan yang sifatnya dipaksakan (enforced tax compliance). Tetapi penelitian ini membuktikan bahwa skala kekuatan otoritas pajak juga diperlukan untuk mendapatkan kepatuhan sukarela (voluntary tax compliance).

Kata kunci: teori slopey slope, wajib pajak orang pribadi, kepatuhan pajak sukarela, kepatuhan pajak yang dipaksakan, PLS-SEM

${ }^{1}$ Corresponding author:

Email: atik@perbanas.id 


\section{INTRODUCTION}

One manifestation of the nation's independence is its ability to finance the development by using funds originating from domestic potential. Taxes are currently a mainstay of state revenues compared to revenues from other sectors. Over the past five years since 2011, revenues from tax have averaged more than $75 \%$ of total domestic income (Kemenkeu, 2017). Thus, the role of tax as a source of funding for the State Budget (APBN) is quite significant but the level of the individual taxpayer compliance was still low even though in 2018 is better than the previous year. The level of compliance of the Individual taxpayer in reporting the annual tax return (SPT) reached $63.9 \%$ in 2018 which is higher than the previous year in 2017 (58.9\%). Specifically for the compliance of the individual non-employee taxpayer levels in 2018 showed a ratio of $40.5 \%$, an increase compared to 2017 which reached 38.8\% (Putra, 2018). The compliance of taxpayer in Indonesia is still classified as the compliance to meet the applicable tax provisions, not arising from personal awareness. Taxpayers are obedient to pay taxes because fear of being inspected, far of being sanctioned, and charged in a higher tax rates (Surliani and Cardinal, 2014; Cahyonowati, 2011; Jatmiko, 2006; Rustiyaningsih, 2011; and Septarini, 2015). Developing countries generally show this kind of the compliance (Kogler et al. 2013). Russia, who has the lowest level of international transparency among Austria, Hungary and Romania, shows a higher forced level of the compliance compared to the other three countries in matters of taxation. The four countries are the objects of Kogler's research et al. (2013) which differed in economics and culture.

Various factors have underlie previous studies regarding the taxpayer compliance. Devos (2014) divides these factors as the economic variable of deterrence, psychological variables, and fairness. Economic variables can generally be preventive variables that can provide a deterrent effect on the individual nonemployee taxpayer compliance. This variable was first developed by Allingham and Sandmo (1972) in deterrence theory. Each individual in making decisions and reporting tax is based on a logical consideration between the benefits and risks faced. Tax evasion may be avoided by taxpayer if the financial benefits of tax evasion are not worth the effort and cost.
The individual non-employee taxpayer compliance is related to the risks faced if it is found to violate the applicable taxation provisions. This is a form of prevention carried out by the tax authority to obtain the taxpayer compliance. The taxpayer is compliant because it avoids high fines and avoids tax audits (Cahyonowati, 2011). The same result shows that the quality of service, the assertiveness of tax sanctions and tax audits both partially and simultaneously affect the compliance (Surliani and Cardinal, 2014).

Previous studies put the power of the tax authorities to obtain the enforced tax compliance, while this research intends to show its relation to the voluntary tax compliance. This is the novelty of this study compared to previous studies because according to Kogler et al. (2013), the power of the tax authority is still needed even for the sake of the voluntary tax compliance even especially in people who still have a low level of the trust in the tax authority.

Previous research in analyzing the taxpayer compliance is generally conducted separately between compliance because of pressure from authority and compliance because of self-awareness. Obedient due to pressure from authority, generally due to economic factors and has been explained by the deterrent theory. Obedient because of self-awareness or due to non-economic factors explained by planned behavior theory. According to planned behavior theory, a person's behavior is basically determined by their intentions and motivations (Ajzen, 1991). A person's attitudes and beliefs interact with social norms so that they affect his consciousness. Based on the theory of planned behavior, the emergence of one's intention to behave is determined by three factors, namely individual beliefs, normative beliefs, and behavioral control beliefs. Taxpayer is the people who intent to participate in paying taxes in accordance with applicable regulations. Such behavior will foster the voluntary tax compliance (Hofman et al. 2008). The taxpayer compliance arise from one's intention to comply with the perception that compliance is easy to implement (Damayanti et al. 2015). If tax professionals have high moral obligations, the intention of the tax compliance is also high, and vice versa (Mustikasari, 2007). The avoidance was also related to spiritual intelligence and emotional intelligence (Salehi et al. 2017). 
Kirchler et al. (2008) attempted to integrate economic and non-economic determinants as well as explaining the taxpayer compliance in slippery Slope theory. Thus this theory is the development of the deterrent theory and planned behavior theory. Slippery slope theory explains the taxpayer compliance based on two dimensions, namely the taxpayer trust and the power of the tax authority (Kirchler et al. 2008). The framework of the relationship between the dimensions is described as a three-dimensional graph. When the taxpayer trust is low and the power of the tax authority is weak, the community will maximize their chances of avoiding tax payments. Thus, the compliance is low. Conversely, if the power of the tax authority is high despite of the low trust, the opportunity to avoid taxes will also be lower. This condition increases taxpayer compliance even though such compliance occurs due to compulsion. Likewise, when the trust in authority is high even though the power of the tax authority is weak, taxpayer can still obey. Such compliance is called the voluntary compliance. Taxpayer believes in the good intentions of the tax authority in carrying out its task of raising funds for the country's development. Thus, the relationship of the trust and the power of the tax authority towards the taxpayer compliance is a dynamic and mutually attractive relationship.

Several studies on the taxpayer compliance based on the slippery slope theory have been conducted in several countries. Muehlbacher et al. (2011) tested the theory of Slippery Slope in three countries with different taxation systems and economies, namely Austria, the United Kingdom, and the Czech Republic. The results of his research concluded that the trust in authority is the strongest predictor of the voluntary compliance. In 2013 the slippery slope theory was re-tested in countries with different cultures and economies, namely Austria, Hungary, Romania and Russia by Kogler et al. (2013). The results of his research indicate that the highest taxpayer compliance with low tax evasion occurs in conditions of the trust and high the power of the tax authority. Conversely participants in the low trust group and the power of the weak tax authority showed low intention to comply and a high intention to avoid taxes. The research was conducted by the experimental method.

In Indonesia, researches using the slippery slope theory have not been done much. This study tries to develop the slippery slope theory by linking the scale of the power of the tax authority which is part of the power of the tax authority on voluntary compliance. According to Kogler et al. (2013), the voluntary compliance can be realized in addition to the existence of the trust, the power of the tax authority must also be high, especially in the case of taxpayers who have low levels of the trust in authority.

In addition, the fairness of the tax system is also a determinant of the voluntary tax compliance. The fairness is needed in tax collection because psychologically the community considers that tax is a burden. The tax paid does not necessarily provide good direct lead, so fair treatment is required for each citizen. Fair means the same treatment for taxpayers who are in the same economic situation and taxed according to the ability and benefits they receive. The fairness of the tax system has a positive effect on the compliance of corporate taxpayer (Syakura and Baridwan, 2014). Several studies have highlighted procedural fairness in relation to the taxpayer compliance. The procedural fairness together with the probability of being detected and the severity of tax sanctions are proven to affect the voluntary compliance through individual tax norms (Dijke and Verboon, 2010). Likewise in Siahaan's study (2012), the tax fairness was proven to directly and indirectly influence the voluntary compliance, but in Ratmono's (2014) the procedural fairness research was not proven to moderate the relationship between the fines and the trust in the tax compliance. The lack of previous research that highlights the fairness of the tax system on the voluntary compliance prompts researchers to prove this.

\section{METHODS}

This study is a quantitative research that aims to explain and analyze the causal relationship between the trust, the fairness of the tax system, and the scale of the power of the tax authority to the voluntary taxpayer compliance and intends to prove the research hypothesis. The analysis was assisted with Smart-PLS3 statistical software. According to Sholihin and Ratmono (2013) this PLS is appropriate to be used to analyze research aimed at: 1) predicting or explaining constructs or latent variables that are being targeted, expanding on existing theories and formulating structural relationships with fairly complex models 2 ) There are constructs in this research which are formative in nature. 3) Data quality is more lax, ie the sample size does not have to be large and the data does not have to be normally distributed. 
The research data was obtained through a survey method from the population of individual taxpayers whose have businesses living in Jakarta and surrounding areas. The individual non-employee taxpayer was chosen as the research analysis unit because in general he is directly related to tax decision making both for himself and his business. The Jakarta and surrounding areas were chosen as survey areas because tax revenue in this region showed good performance although according to Nababan (2019) tax revenue in DKI Jakarta region in 2019 only reached $74.3 \%$ of the target of IDR 44,540 trillion. DKI Jakarta regional government's regional tax and retribution agency continues to pursue its achievement targets over the remaining time.

Determination of the sample by the convenience method due to limitations in accessing taxpayer personal data at the tax directorate general's office. Taxpayer personal information is confidential. While data on the number of taxpayer in the Jakarta area is still possible to be obtained, this study in determining the number of samples using the Slovin method with an error rate of 10\% (Sugiyono, 2006).

$\mathrm{N}=155.352$ (Total individual taxpayer required annual tax return/SPT at regional offices in DKI Jakarta as of December 31, 2016)

$\mathrm{e} \quad=10 \%=0,1$

$\mathrm{e}^{2}=0,1^{2}=0,01$

$\mathrm{n}=155.352 /(1+(155.352 \times 0,01))$

$\mathrm{n}=155.352 / 1555$

$\mathrm{n}=99,90$ dibulatkan 100 orang/ responden

Thus based on the Slovin formula the number of samples to be taken is 100 people/ respondents. Respondents in this study are the individual non-employee taxpayer who carry out business activities or freelance. They are required to submit the annual tax return and as a form of accountability in meeting tax regulations (2007 KUP Law article 3 paragraph1).

Table 1 shows that the largest respondent's line of business was services by $47 \%$, then trading, $19 \%$. While the production business is quite small, only $3 \%$. Respondents' businesses that are not accommodated in the service, trade and production group are included in the other groups, amounting to $30 \%$. Generally in low- income respondents $<4,500,000$ IDR per month, which is $35 \%$. The next largest respondents are those who earn 4,500,000 -10,000,000 IDR per month, 32\% and 28\% of respondents who earn 10,000,000 - 50,000,000 IDR per month. The average respondent is female. That is $56 \%$, while the rest are male, $44 \%$. Respondents were generally mature because most were aged $41-60$ years, at $61 \%$. The next largest respondent was $20-40$ years old, $35 \%$.

The analysis was assisted with Smart-PLS3 statistical software. According to Sholihin and Ratmono (2013) this PLS is appropriate to be used to analyze research aimed at: 1) predicting or explaining constructs or latent variables that are being targeted, expanding on existing theories and formulating structural relationships with fairly complex models; 2 ) There are constructs in this research which are formative in nature; 3) Data quality is more lax, ie the sample size does not have to be large and the data does not have to be normally distributed.

Table 1. Demographics of respondents

\begin{tabular}{|c|c|c|}
\hline Variable & Quantity & Percentage \\
\hline \multicolumn{3}{|l|}{ Business Fields } \\
\hline Services & 47 & $47 \%$ \\
\hline Trading & 19 & $19 \%$ \\
\hline Manufacturing & 4 & $4 \%$ \\
\hline Other & 30 & $30 \%$ \\
\hline \multicolumn{3}{|c|}{ Average Revenue per-month } \\
\hline$<\operatorname{Rp} 4,500,000$ & 35 & $35 \%$ \\
\hline $\begin{array}{l}\mathrm{Rp} \quad 4,500,000-<\mathrm{Rp} \\
10,000,000\end{array}$ & 32 & $32 \%$ \\
\hline $\begin{array}{l}\text { Rp 10,000,000 - < Rp } \\
50,000,000\end{array}$ & 28 & $28 \%$ \\
\hline Rp 50,000,000 - more & 2 & $3 \%$ \\
\hline \multicolumn{3}{|l|}{ Gender } \\
\hline Female & 56 & $56 \%$ \\
\hline Male & 44 & $44 \%$ \\
\hline \multicolumn{3}{|l|}{ Age } \\
\hline$<20$ year & 3 & $3 \%$ \\
\hline $20-40$ year & 35 & $35 \%$ \\
\hline $41-60$ year & 61 & $61 \%$ \\
\hline$>61$ year & 1 & $1 \%$ \\
\hline Total & 100 & $100 \%$ \\
\hline
\end{tabular}


Based on the smart PLS 3 statistical program, the research model is presented through the relationship of the outer model and the inner model. The outer model in this study illustrates the reflective relationship between variables and indicators. The inner relationship model describes the relationship between latent variables. Outer loading values for all instrument indicators that reflect fulfilled the role of thums is 0,7 . Before analyzing the inner relationships of the model, data quality testing is done through validity and reliability tests with the convergent test and discriminant validity. The role of thums of the validity test is AVE $>0.5$. While the reliability test by measuring Cronbach Alpha and Composite Reliability. The role of thums of the Cronbach Alpha value is $>0.7$ and Composite Reliability is $>0.7$ (Ghozali and Latan, 2015 and Hair et al. 2014).

\section{Hypothesis Development}

The voluntary tax compliance is the behavior and attitude of taxpayers who obey to pay taxes voluntarily without being affected by applicable taxation regulations (Muehlbacher et al. 2011; Kogler et al. 2013; and Ratmono, 2014). The voluntary tax compliance grows from the awareness to obey and pay taxes according to applicable regulations. This awareness arises because of the taxpayer understanding of the need for sources of funds needed to finance government activities. The taxpayer obliged to participate in activities with other citizens and wanted to help the needy. For taxpayers who voluntarily comply, paying taxes is a form of fairness as a citizen. Taxpayer has the awareness to pay taxes and is not affected by the opportunity to avoid paying taxes even though there are opportunities to do so. The voluntary tax compliance is certainly more desirable by the authorities because it can reduce costs for maintaining the individual taxpayer compliance, such as the tax audit fees, the tax collection fees, and the tax dispute costs. In addition, the voluntary tax compliance can create a synergistic and productive climate both for the tax authorities and for the taxpayers. The theoretical framework (Figure 1) used in formulating hypotheses in this study is as follows:

The trust and the voluntary taxpayer compliance

The citizens of developed countries basically prefer the voluntary tax compliance rather than the enforced tax compliance (Kirchler and Muehlbacher, 2010; Muehlbacher et al. 2011; and Kogler et al. 2013). This is because of the high level of awareness in paying taxes. In developed countries, citizens understand that the government needs funds to carry out development so that paying taxes is voluntary. On the other hand, facilities are available with the support of advanced and transparent information systems that make it easy for each citizen to access government activities as a control.

Some research in Indonesia that can be identified as the trust is understanding and knowledge of applicable tax regulations, generally showing a positive effect on the tax compliance (Hardiningsih and Yulianawati, 2011; Kariyoto, 2011; and Surliani and Cardinal, 2014). This raises hopes for the growth of voluntary taxpayer compliance. It is hoped that citizens who are familiar with the taxation regulations will lead to voluntary behavior. The trust is proven to affect one's moral tax (Vythelingum et al. 2017). The trust that is implemented as competence, consistency, service, and transparency of tax authorities has a positive effect on the tax compliance (Syakura and Baridwan, 2014). This research intends to provide additional empirical evidence on this matter.

H1: The trust has a positive effect on the voluntary taxpayer compliance

The fairness of the tax system and the voluntary taxpayer compliance

This research places the fairness of the tax system that is predicted to influence the voluntary taxpayer compliance. Syakura and Baridwan (2014) use tax justice as a variable that influences the compliance of the corporate taxpayer. In the study of Vythelingum, et al. (2017) the fairness of the tax system is correlated with a person's moral tax. The fairness of the tax system intended in this study is as stated in the four maxims of Adam Smith's tax imposition theory (1776). The principles of the four maxims in tax collection are equality, certainty, convenience, and economy.

Ratmono (2014) highlights the effect of the procedural fairness on fines in influencing the voluntary tax compliance. However, the results of his research were not supported. In the study of Dijke and Verboon (2010), the procedural fairness together with the probability of being detected and the severity of tax sanctions have been proven to influence the voluntary compliance through personal tax norms. Siahaan (2012) proves 
that tax justice is proven both directly and indirectly to affect the voluntary tax compliance. The lack of previous research that highlights the fairness of the tax system on the voluntary tax compliance prompts researchers to prove this hypothesis.

H2: The fairness of the tax system has a positive effect on the voluntary taxpayer compliance

The scale of the power of the tax authority and the voluntary taxpayer compliance

According to the deterrent theory, a person's behavior is based on his logical thinking of the benefits, costs and risks of the actions chosen (Allingham and Sand, 1972). In connection with the tax compliance, a person is described to consider the benefits and risks if they intend to avoid taxes. The taxpayer will avoid the risk of tax avoidance if the benefits of the avoidance are not proportional to the benefits. Generally a person will avoid all forms of loss caused by violating the law. Thus, forms of pressure from the tax authority can have a deterrent effect for taxpayers who intend to avoid taxes, such as imposing severe sanctions/fines and even imprisonment for tax crimes, imposing higher tariffs if proven to have committed violations, a high possibility of being examined, a high probability of detection for taxpayers who intend to commit tax fraud, to the loss of the opportunity to get taxation facilities if proven intending to violate taxes.

In previous studies, it was generally concluded that forms of the tax authority pressure proved to have a positive effect on the taxpayer compliance (Hardiningsih and Yulianawati, 2011; Rapina; Jerry and Carolina, 2011; Kariyoto, 2011; Kariyoto, 2016; Cahyonowati, 2011; Surliani and Cardinal, 2014 and Syakura and Baridwan, 2014). Especially in developing countries, the taxpayer compliance is proven to arise due to pressure from the tax authorities (Kogler et al. 2013). Such taxpayer compliance is classified as the enforced tax compliance. This is in a line with the slippery slope theory which explains that the taxpayer compliance occurs due to the mutually interesting relationship between the power of the tax authority on the one hand and the trust on the other. The power of the tax authority fosters the enforced tax compliance and the trust fosters the voluntary tax compliance.
Nevertheless, Kogler et al. (2013) proved in his experiment that the voluntary tax compliance obedience in fact also requires the power of the tax authority. Taxpayer has the perception that the tax authorities who have sufficient authority cannot be played by taxpayer who intend to avoid taxes. Taxpayer feels that the tax authority can carry out their duties properly if sufficient authority is provided. Thus, the power of the tax authority is still needed to foster the voluntary compliance, especially for citizens who have low levels of the trust (Kogler et al. 2013).

This study also intends to examine the relationship between the scale of the power of the tax authority and the voluntary tax compliance. In a previous study conducted by Dijke and Verboon (2010), the possibility of detection and tax penalties as an element of the power of the the tax authority positively affected the voluntary tax compliance through personal tax norms. In Ratmono's research (2014), tax penalties also affect the voluntary compliance through the trust. In contrast to the study of Rablen (2014), tax audits do not affect the voluntary tax compliance. Based on the above arguments the research hypothesis is formulated as follows:

H3: The scale of the power of the tax authority has a positive effect on the voluntary taxpayer compliance.

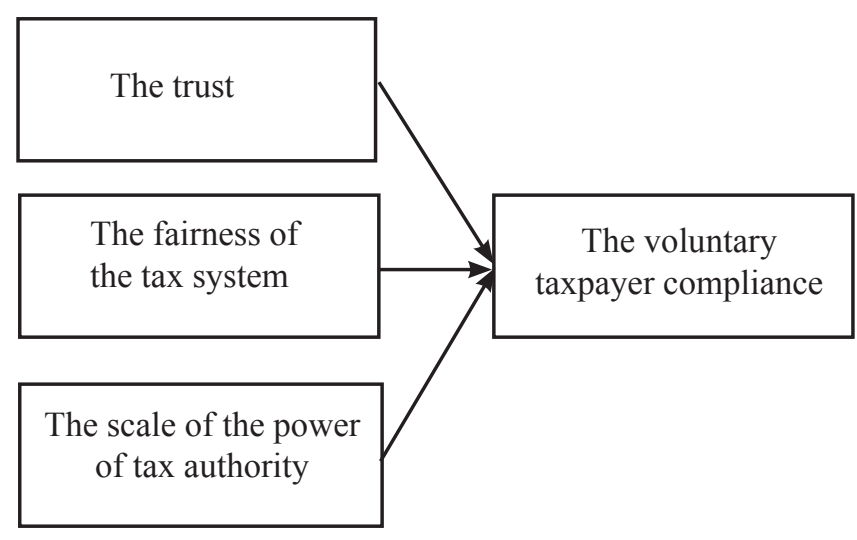

Figure 1. Research framework 


\section{RESULTS}

The test results are presented through testing the relationship between the outer model and the inner model. Outer model test is done by running data twice. In the first running data there are two instrument indicators whose outerloading values are between 0.4 - 0.7. According to Hair, et al., (2014), these indicators must be deleted if the deletion increases the AVE and CR values as required, namely AVE $>0.5$ and $C R$ value $>$ 0.7. Therefore, in the next running data the instrument indicator has fulfilled the role of thums (Hair et al. 2014).

Before data analysis is performed, data quality testing is carried out. Test the quality of the data with a validity and reliability test. The PLS algorithm test results show that all constructs have fulfilled the role of thums of the validity test $\mathrm{AVE}>0.5$. Likewise, the reliability test also fulfilled the Cronbach Alpha test with role of thums $>$ 0.7 and Composite Reliability $>0.7$ (Hair et al. 2014).

Table 2 presents the results of the validity and reliability testing algorithm between before and after deleting the instrument indicators that do not meet the role of the thums test. Thus the quality of the data meets the requirements and can be continued to the inner model analysis.
Table 3 presents the results of testing the inner model to estimate the relationship between latent variables. This table presents the results of a hypothesis test that shows that the voluntary taxpayer compliance is affected by the fairness of the tax system, the trust and the scale of the power of the tax authorities. This can be seen at the significant value $<0.05$ which indicates that each variable influences the voluntary taxpayer compliance. The value of the trust coefficient and the scale of the power of the tax authority each showed a positive direction of 0.570 and 0.362 . However, in the fairness of the tax system, although it affects the voluntary taxpayer compliance at a significant level of 0.10 because the direction is negative, this hypothesis is rejected. The fairness of the tax system does not have a positive effect on the voluntary taxpayer compliance. The coefficient value of the fairness of the tax system was -0.179 .

$\mathrm{R} 2$ value indicates $52.8 \%$, significant. This shows that the relationship between latent variables consisting of the trust, the scale of the power of the tax authority, and the fairness of the tax system in explaining the voluntary tax compliance shows a value of $52.8 \%$, the remaining $47.2 \%$ indicates that the voluntary tax compliance is explained by other variables not discussed in this research.

Table 2. Convergent validity and reliability

\begin{tabular}{|c|c|c|c|c|c|c|}
\hline \multirow[b]{2}{*}{ Constructs } & \multicolumn{3}{|c|}{ Initial } & \multicolumn{3}{|c|}{ Iteration } \\
\hline & $\mathrm{AVE}>0.5$ & $\mathrm{CR}>0.7$ & $\begin{array}{l}\text { Cronbach's } \\
\text { Alpha }>0.7\end{array}$ & $\mathrm{AVE}>0.5$ & $\mathrm{CR}>0.7$ & $\begin{array}{l}\text { Cronbach's } \\
\text { Alpha }>0.7\end{array}$ \\
\hline The fairness of the tax system (KSP) & 0.497 & 0.752 & 0.653 & 0.663 & 0.850 & 0.758 \\
\hline The trust (KWP) & 0.644 & 0.942 & 0.930 & 0.644 & 0.942 & 0.930 \\
\hline $\begin{array}{l}\text { The scale of the power of the tax authority } \\
\text { (SKOP) }\end{array}$ & 0.669 & 0.857 & 0.755 & 0.669 & 0.858 & 0.755 \\
\hline The voluntary tax compliance (KS) & 0.638 & 0.923 & 0.899 & 0.714 & 0.937 & 0.919 \\
\hline
\end{tabular}

Table 3. Inner model and hypothesis decision

\begin{tabular}{lcccc}
\hline \multicolumn{1}{c}{ Hypothesis } & Path Coeficient & Significance & Decision & $\mathrm{R}^{2}$ \\
\hline $\mathrm{KSP} \rightarrow \mathrm{KS}$ & -0.79 & $0.55^{* *}$ & Rejected & 0.528 (significant) \\
$\mathrm{KWP} \rightarrow \mathrm{KS}$ & 0.570 & $0.000^{*}$ & Accepted & \\
$\mathrm{SKOP} \rightarrow \mathrm{KS}$ & 0.362 & $0.000^{*}$ & Accepted & \\
\hline
\end{tabular}

*significant at the 0.05 level; **significant at the 0.10 level 
The results of this study indicate that the trust, the fairness of the tax system and the scale of the power of the tax authority influence the voluntary taxpayer compliance. The trust positively influences. This research supports the slippery slope theory which states that the voluntary requires the trust. The taxpayer compliance which based on the slippery slope theory has two dimensions, namely the trust and the power of the tax authority. Relationships between the three are described as mutually attractive relationships. When the taxpayer trust is low and the authority is weak, the community will maximize their opportunities to avoid taxes. Conversely, if the trust is high even though the tax authority is weak, citizens can comply and this is what is called the voluntary tax compliance (Kirchler et al. 2008). Thus, testing this hypothesis provides an additional empirical evidence which corroborates the conclusion that the trust is related to the voluntary tax compliance. Kogler et al. (2013) and Kirchler et al. (2014) in their research said that the voluntary tax compliance can be realized if there is the taxpayer trust.

Muehlbacher et al. (2011) in their research showed that the trust in authority is the strongest predictor of the voluntary tax compliance. Their research was conducted in three countries with different economic and taxation systems, namely in Austria, the United Kingdom, and the Czech Republic. This study is also in line with research conducted by Kogler et al. (2013) which concluded that the highest tax payer compliance with low embezzlement occurred in conditions of the trust and the power of the tax authorities which were also high. On the other hand, the experimental group which had low the trust showed low intention to obey and high intention to avoid tax payment. Experimental research by Kogler et al. (2013) was carried out in four countries with different cultures and economies, namely Austria, Hungary, Romana, and Russia. Research in Indonesia has provided much empirical evidence that the trust has a positive effect on the compliance (Ratmono, 2014; Siahaan, 2012; Rahmawaty et al. 2011; and Syakura and Baridwan, 2014).

The trust arises from consciousness which is a person's internal product. Based on the theory of planned behavior explained that a person's behavior is influenced by his intentions, namely individual beliefs, normative beliefs, and control beliefs (Ajzen, 1991). The compliance behavior reflects a person's belief or judgment on his understanding of the tax imposed on him and also on the intention shown to comply with taxation. So in a person has a high understanding of the funding needs required by the government and as citizens do intend to participate. The taxpayer awareness that is identified as the trust influences the tax compliance (Septarini, 2015; and Jatmiko, 2006). In Kariyoto's research (2016), Tax payer awareness increases the performance of the tax authorities. In a person there is indeed an intention to pay taxes especially if there is the trust in the tax authority.

The scale of the power of the tax authority has a positive effect on the voluntary tax compliance. The results of this study are in line with the explanation of slippery slope theory which says that the tax compliance arises from the power of attraction between the power of the tax authority on the one hand and the trust of the taxpayer on the other. For citizens who still have low level of the trust in the authority, the power of the tax authority will be more dominant influencing compliance, even for voluntary compliance (Kogler et al. 2013).

The taxpayer voluntarily pays tax if the tax authority has sufficient authority to impose tax on each of its citizens. The taxpayer is compliant in paying taxes because the power of authority guarantees that every citizen of the community does the same thing, namely paying taxes according to the provisions. Citizens will obey voluntarily if the tax authority has the power/ authority that can force each taxpayer to comply in paying taxes. Thus, the taxpayer has a perception that the tax authorities cannot be mocked by taxpayer whos intend to avoid taxes. Dijke and Verboon (2010) in their research also concluded that the possibility of detection and the tax sanctions which are forms of pressure from the tax authority affect the voluntary compliance through personal tax norms. Dijke and Verboon's research (2010) was conducted in the Netherlands. The Ratmono (2014) study conducted in Semarang concluded that tax fines through the trust had a positive effect on the voluntary compliance.

The fairness of the tax system has a negative effect on the voluntary compliance. This is an interesting thing from the results. The more fair of the tax collection is the more not voluntary in paying taxes. Taxpayers who are respondents in this study are generally low income, as shown in Table 1. Generally they expect taxation regulations to be more inclined towards them. It is difficult to finance everyday life let alone pay taxes. The fairness for the tax system is appropriate 
when the community is homogeneous prosperous but if there is still economic inequality in society then the justice of the tax system is not able to have a positive effect on the taxpayer compliance. The results of this study are in line with research by Ratmono (2014), procedural fairness does not support the relationship of tax fines with the voluntary compliance. However, in the research of Dijke and Verboon (2010), procedural fairness together with the probability of being detected and the severity of tax sanctions have been proven to affect the voluntary compliance through personal tax norms. Dijke and Verboon's research (2010) was conducted in the Netherlands. In Indonesia, the results of the study are in line with the research of Dijke and Verboon (2010) conducted by Siahaan (2012) at taxpayer in Surabaya. Tax fairness has both direct and indirect effects on the voluntary compliance.

\section{Managerial Implications}

This study provides additional empirical evidence that basically the taxpayer who became a respondent in this study had a voluntary spirit in taxation. The individual taxpayers trust can increase compliance to pay taxes. Therefore things that can increase trust are improved, such as resolving cases of tax evasion by unscrupulous tax officials, creating transparency in the receipt and use of tax proceeds. In addition, compliance voluntary also still requires the power of the tax authority guarantee that every citizen comply in paying taxes. The taxpayer must pay taxes according to the provisions and cannot fool the tax authorities with the intention of avoiding taxes. Therefore the tax authorities must expertise in detecting tax violations, being consistent and not selective in applying applicable taxation regulations, providing fast and responsive services to taxpayer.

The voluntary compliance is actually more efficient because it does not require substantial oversight costs to ensure the compliance of its citizens. In addition, the voluntary compliance can create a synergistic atmosphere. The relationship in a synergistic atmosphere between the tax authority and taxpayer can create a productive climate.

\section{CONCLUSIONS AND RECOMMENDATIONS}

\section{Conclusions}

This study concludes that the voluntary taxpayer compliance is influenced by the trust, fairness of the tax system and the scale of the power of the tax authority. Thus, it is important for tax authorities to continuously increase the trust of taxpayer. Things that can reduce the level of taxpayer trust immediately corrected, such as completing cases of the tax evasion by unscrupulous tax officials, creating transparency in the receipt and use of tax proceeds, and various efforts that can increase taxpayer trust because the trust is proven to increase the voluntary compliance. The voluntary compliance is certainly more desirable because it does not require large oversight costs in addition to that it can also create a synergistic and productive atmosphere both for the tax authorities and for taxpayer.

Likewise, the scale of the power of the tax authority also proved to have a positive effect on the voluntary compliance. The results of this study can be used as input for the tax authorities to identify the behavior of their citizens. The government needs to make continuous efforts to improve its performance. The authority possessed by the authority is proven to be a means to increase the voluntary compliance. Tax officials need to improve their competence in technical knowledge and expertise in the field of taxation, including expertise in detecting tax violations, being consistent and not selective in applying applicable taxation regulations, providing fast and responsive services to taxpayer.

The fairness of the tax system actually reduces the voluntary compliance. The individual taxpayers expected tax regulations to be more inclined towards them. They were more concerned with paying less tax even if this is considered unfair. What is important for them is paying less tax than they should. Thus if they have to pay a fair taxes, they actually become not voluntary

\section{Recommendations}

This study is more targeted at low-income respondents. Those who are less fortunate actually want government alignments that are more inclined towards them. A sense of fairness actually means being willing to compensate benefits for those who are less fortunate. Thus, the 
fairness of the tax system still needs to be proven in future studies, especially those that can reach taxpayer at all economic levels.

\section{REFERENCES}

Ajzen I. 1991. The theory of planned behavior. Organisation Behavior and Human Decision Process 211: 179-211. https://doi. org/10.1016/0749-5978(91)90020-T.

Allingham MG, Sandmo A. 1972. Income tax evasion: a theoretical analysis. Journal of Public Economic 1: 323-338. https://doi.org/10.1016/00472727(72)90010-2.

Cahyonowati N. 2011. Model moral dan kepatuhan perpajakan: wajib pajak orang pribadi. Jurnal Akuntansi dan Auditing Indonesia 15(2): 161177.

Damayanti TW, Sutrisno T, Subekti I, Baridwan Z. 2015. Trust and uncertainty orientation: an efforts to create tax compliance in social psychology framework. Procedia Social and Behavioral Sciences 211: 938-944. https://doi. org/10.1016/j.sbspro.2015.11.124.

Devos K. 2014. Factors Influencing Individual Taxpayer Compliance Behaviour. Netherlands: Springer. https://doi.org/10.1007/978-94-007-7476-6.

Dijke MR, Verboon P. 2010. Trust in authorities as a boundary condition to procedural fairness effects on tax compliance. Journal of Economic Psychology 31(1): 80-91. https://doi. org/10.1016/j.joep.2009.10.005.

Ghozali I, Latan H. 2015. Partial Least Squares. Konsep, Tehnik dan Aplikasi Menggunakan SmartPLS 3.0 (Second Edi). Semarang: Universitas Diponegoro.

Hair JF, Hult GT, Ringle MR, Sarstedt M. 2014. A Primer on Partial Least Squares Structural Equation Modeling (PLS-SEM ). United States of America: SAGE Publications, Inc.

Hardiningsih P, Yulianawati N. 2011. Faktor-faktor yang mempengaruhi kemauan membayar pajak. Dinamika Keuangan dan Perbankan 3(1): 126142.

Hofman E, Hoelzl E, Kirchler E. 2008. Preconditions of voluntary tax compliance knowledge and evaluation of taxation, norms, fairness, and motivation to cooperate. Journal of Psychology 216(4): 209-217. https://doi.org/10.1027/00443409.216.4.209.
Jatmiko AN. 2006. Pengaruh Sikap Wajib Pajak pada Pelaksanaan Sanksi Denda, Pelayanan Fiskus dan Kesadaran Perpajakan terhadap Kepatuhan Wajib Pajak (Studi Empiris terhadap Wajib Pajak Orang Pribadi di Kota Semarang)[thesis]. Semarang: Program Magister Akuntans, Program Pascasarjana Universitas Diponegoro.

Kariyoto. 2011. Pengaruh Reformasi Perpajakan, Audit Perpajakan, Kesadaran dan kepatuhan Wajib Pajak terhadap Kinerja Perpajakan [dissertation], Malang: Program Doktor Ilmu Akuntansi, Program Pascasarjana Fakultas Ekonomi dan Bisnis Universitas Brawijaya.

Kariyoto. 2016. The Effect of Tax Reform and Tax Auditing on Its Performance (Studies in East Java Regional Office of the Directorate General of Taxes III Malang). International Journal of Social and Local Economic Governance (IJLEG) 2(1): 49-58. https://doi.org/10.21776/ ub.ijleg.2016.002.01.6.

[Kemenkeu] Kementerian Keuangan Republik Indonesia. 2017. Nota Keuangan dan Rancangan Anggaran Pendapatan dan Belanja Negara Tahun Anggaran 2017. Jakarta: Kementerian Keuangan Republik Indonesia.

Kirchler E, Hoelzl E, Wahl I. 2008. Enforced versus voluntary tax compliance: the "slippery slope" framework. Journal of Economic Psychology 29: 210-225. https://doi.org/10.1016/j. joep.2007.05.004.

Kirchler E, Muehlbacher S. 2010. Tax compliance by trust and power of authorities. International Economic Journal 24(4). https://doi.org/10.1080 /10168737.2010.526005.

Kirchler E, Kogler C, Muehlbacher S. 2014. Cooperative Tax Compliance: From Deterrence to Deference. Current Directions in Psychological Science 23(2): 87-92. https://doi. org/10.1177/0963721413516975

Kogler C, Batrancea L, Nichita A, Pantya J, Belianine A, Kirchler E. 2013. Trust and power as determinants of tax compliance: Testing the assumptions of the slippery slope framework in Austria, Hungary, Romania and Russia. Journal of Economic Psychology 34: 169-180. https:// doi.org/10.1016/j.joep.2012.09.010.

Muehlbacher S, Kirchler E, Schwarzenberger H. 2011. Voluntary versus enforced tax compliance: empirical evidence for the "slippery slope" framework. European Journal of Law and Economics 32: 89-97. https://doi.org/10.1007/ 
s10657-011-9236-9.

Mustikasari E. 2007. Kajian Empiris Tentang Kepatuhan Wajib Pajak Badan di Perusahaan Industri Pengolahan di Surabaya. In Simposium Nasional Akuntansi 10 (pp. 1-41). Universitas Hasanudin, Makasar.

Nababan HF. 2019. Tersisa dua bulan, penerimaan pajak DKI baru 74,30 persen. https://kompas. $\mathrm{id} / \mathrm{baca} /$ utama/2019/11/06/tersisa-dua-bulanpenerimaan-pajak-dki-baru-7430-persen/

Putra AD. 2018. Rasio kepatuhan pelaporan spt wajib pajak orang pribadi meningkat. Retrieved from http:// ekonomi.kompas.com/ read/ 2018/04/02/180752626/rasio-kepatuhanpelaporan-spt-wajib-pajak-orang-pribadimeningkat

Rablen MD. 2014. Audit probability versus effectiveness: the beckerian approach revisited. Journal of Public Economics Theory 16(2), 322-342. https://doi.org/10.1111/jpet.12062.

Rahmawaty Ningsih ES, Fadhlia W. 2011. Faktorfaktor yang mempengaruhi kemauan membayar pajak. Jurnal Telaah \& Riset Akuntansi 4(2).

Rapina J, Carolina Y. 2011. Pengaruh penerapan sistem administrasi perpajakan modern terhadap kepatuhan wajib pajak (survey terhadap kantor pelayanan pajak pratama bandung cibeunying). Jurnal Riset Akuntansi 3(2).

Ratmono D. 2014. Model kepatuhan perpajakan sukarela: peran denda, keadilan prosedural, dan kepercayaan terhadap otoritas pajak. Jurnal Akuntansi Dan Auditing Indonesia 18(1): 42-64. https://doi.org/10.20885/jaai.vol18.iss1.art4.

Rustiyaningsih S. 2011. Faktor Faktor yang mempengaruhi kepatuhan wajib pajak. Widya
Warta 2, 44-54. https://doi.org/ISSN 0854-1981

Salehi M, Mirzaee MA, Yazdani M. 2017. Spiritual and emotional intelligences, financial performance, tax avoidance and corporate disclosure quality in Iran. International Journal of Law and Management 59(2): 237-256. https://doi. org/10.1108/IJLMA-11-2015-0059

Septarini DF. 2015. Pengaruh pelayanan, sanksi, dan kesadaran wajib pajak terhadap kepatuhan wajib pajak orang pribadi di KPP Pratama Merauke. Jurnal Ilmu Ekonomi \& Sosial VI(1): 44-55.

Sholihin M, Ratmono D. 2013. Analisis SEM-PLS dengan WarpPLS 3.0 (Edisi 1). Yogyakarta: Andi Offset.

Siahaan FOP. 2012. The influence of tax fairness and communication on voluntary compliance : trust as an intervening variable. International Journal of Business and Social Science 3(21), 191-198.

Sugiyono. 2006. Statistika untuk Penelitian. Cetakan ke 10. Bandung: CV Alfabeta.

Surliani, Kardinal. 2014. Influence of Understanding, Service Quality, Assertion of Tax Sanction, and Taxation Auditing on Taxpayer Compliance on KPP Ilir Barat, Indonesia. Http://Eprints.Mdp. Ac.Id/Id/Eprint/1120, 1-7

Syakura MA, Baridwan Z. 2014. Determinan perencanaan pajak dan perilaku kepatuhan wajib pajak badan. Jamal 5(2):185-201. https://doi. org/10.18202/jamal.2014.08.5017.

Vythelingum P, Soondram H, Jugurnath B. 2017. An assessment of tax morale among mauritian taxpayers. Journal of Accounting and Taxation 9(1):1-10. https://doi.org/10.5897/ JAT2016.0224 